\title{
ASSESSMENT OF POPULATION CHARACTERISTICS AND HABITAT USE OF PODOCNEMIS VOGLI (MÜLLER 1935) DURING A REPRODUCTIVE SEASON AT THE BOJONAWI PRIVATE NATURE RESERVE (VICHADA DEPARTMENT, COLOMBIA) EVALUACIÓN DE LAS CARACTERISTICAS DE LAS POBLACIONES Y EL USO DE LOS HÁBITATS DE PODOCNEMIS VOGLI (MÜLLER 1935) DURANTE UNA TEMPORADA REPRODUCTIVA EN LA RESERVA NATURAL PRIVADA DE BOJONAWI (DEPARTAMENTO DE VICHADA, COLOMBIA)
}

\author{
Ana M. Sepúlveda-Seguro ${ }^{1}$, Vivian P. Páez ${ }^{1 *}$, Marley T. Gómez-Rincón ${ }^{1}$, Mónica A. Morales- \\ BETANCOURT ${ }^{2}$ \& CARLOS A. LASSO ${ }^{2}$ \\ ${ }^{1}$ Grupo Herpetológico de Antioquia, Instituto de Biología, Universidad de Antioquia, Medellín, Colombia \\ ${ }^{2}$ Programa Ciencias Básicas de la Biodiversidad, Instituto de Investigación de Recursos Biológicos Alexander von Humboldt, Bogotá, Colombia \\ *Correspondence: vivianpaezı@gmail.com
}

Resumen.- Realizamos un breve estudio en la Reserva Natural Privada Bojonawi (Departamento de Vichada, Colombia) en tres tipos de macrohábitats acuáticos para caracterizar el uso del hábitat, la estructura poblacional y la fenología reproductiva de Podocnemis vogli durante una temporada reproductiva. También reevaluamos el grado de dimorfismo sexual en esta especie. Para maximizar las tasas de captura, utilizamos tres métodos: trampas tipo embudo, redes de trasmallo y captura manual. Solo las trampas tipo embudo pudieron usarse de manera estandarizada en los tres macrohábitats. Capturamos 149 individuos en todas las clases de edad / tamaño y obtuvimos i1 recapturas. Al estandarizar el esfuerzo de muestreo con las trampas tipo embudo en todos los macrohábitats, comparamos el uso del hábitat y la estructura de clase entre los hábitats durante esta temporada reproductiva. No hubo diferencias significativas entre los tres macrohábitats en términos de abundancia relativa o distribución de clases de tamaño, pero las proporciones sexuales entre hábitat fueron diferentes, con un exceso de machos en el río y hembras en la laguna. Al igual que con otros congéneres, $P$. vogli es una especie con dimorfismo sexual donde las hembras alcanzan tamaños más grandes. En este estudio documentamos que la longitud pre-cloacal de la cola y la longitud de la uña en el tercer dedo de la pata anterior son las características sexuales secundarias más útiles para sexar subadultos y adultos. Algunas hembras de más de $22 \mathrm{~cm}$ de longitud recta del caparazón tenían huevos calcificados en sus oviductos. Esta especie es abundante dentro de la reserva y parece ser generalista de hábitats, incluyendo el uso de grandes ríos. Se necesita un monitoreo más extenso e intensivo para documentar tasas específicas de supervivencia de las diferentes clases, detectabilidad y dinámica de la población.

Palabras clave.- Dimorfismo sexual, ecología de poblaciones, llanos colombianos, Podocnemididae.

Abstract.- We conducted a short study in the Bojonawi Private Nature Reserve (Vichada department, Colombia) in three types of aquatic macrohabitats to characterize habitat use, population structure and reproductive phenology of Podocnemis vogli during one reproductive season. We also reevaluated the degree of sexual dimorphism in this species. To maximize capture rates, we used three methods: funnel traps, trammel nets, and manual capture. Only the funnel traps could be used in a standardized manner in all three macrohabitats. We captured 149 individuals in all age/size classes and obtained 11 recaptures. Since we were able to standardize sampling effort with the funnel traps in all macrohabitats, we compared habitat use and class structure among habitats during this reproductive season. There were no significant differences among the three macrohabitats in terms of relative abundances or size 
class distributions, but sex ratios differed, with an excess of males in the river and females in the lagoon. As with other congeners, $P$. vogli is a sexually dimorphic species where females attain larger sizes. In this study we documented that pre-cloacal tail length and nail length on the anterior third toe are the most useful secondary sexual characteristics for sexing subadult and adult individuals. Some females larger than $22 \mathrm{~cm}$ straight-line carapace length had calcified eggs in their oviducts. This species is abundant within the reserve and appears to be a habitat generalist, including the use of large rivers. More extensive and intensive monitoring is needed to document specific class survivorship rates, detectabilities and population dynamics.

Keywords.- Colombian llanos, Podocnemididae, population ecology, sexual dimorphism.

\section{INTRODUCTION}

A basic knowledge of life history characteristics and population structure is essential for predicting how changes in population vital rates due to natural or human impacts might affect the population's distribution, patterns of habitat use, and permanence (Heppell, 1998; Böhm et al., 2016; Ripple et al., 2017). For example, in neotropical freshwater turtle species of the Family Podocnemididae, changes in vegetative structure (both floating and riparian), in the width and depth of water bodies, and in the permanence of nesting beaches may lead to changes in home range use and population dynamics (Bernhard \& Vogt, 2012; De Souza et al., 2013; Miorando et al., 2013; Portelinha et al., 2014; Barahona \& López, 2015; Páez et al., 2015; Eisemberg et al., 2016). In addition, in Podocnemis species, both sex ratios and proportions of individuals in the different age/size classes in different habitat types (rivers, channels, wetlands) are not static, because they are affected by seasonal hydrological cycles that differentially affect movement patterns by members of these different groups (Fachin-Terán et al., 2006; Naveda-Rodríguez et al., 2018; Ponce De Leão et al., 2019; Alzate-Estrada et al., 2020).

Not only does spatial and temporal variation in local habitat characteristics complicate the understanding of podocnemidid population structure, the results of studies also depend heavily on the location and duration of the study and on the methods employed (Bernhard \& Vogt, 2012; Bernardes et al., 2014; AlzateEstrada et al., 2020). For some podocnemidid species it has been shown that characteristics of different water bodies are associated with different probabilities of detecting individuals of different size classes. For example, for both P. lewyana and P. erythrocephala, shallower water bodies are associated with a greater proportion of small individuals being registered (GallegoGarcía \& Castaño-Mora, 2008; Bernhard \& Vogt, 2012; GonzálezZárate et al., 2014). However, the greater ease of detecting such individuals in these types of habitat does not mean they avoid deeper water bodies (Páez et al., 2015; Alzate-Estrada et al., 2020). Several other studies on other turtle species also have documented differences in detectabilities depending on sex and/or size class (reviewed by Tesche \& Hodges, 2015). Finally, the different capture methods used to study podocnemidids are known to have biases in terms of the sexes and size classes they sample (Bernhard \& Vogt, 2012; De Souza et al., 2013; Bernardes et al., 2014; Portelinha et al., 2014). In the few long-term studies on these species, one of the patterns that emerges is that most of the population is comprised of juvenile individuals, small females, and males, but the scarcer larger females are difficult to recapture (Bernhard \& Vogt, 2012; Bernardes et al., 2014; Portelinha et al., 2014; Alzate-Estrada et al., 2020).

In Colombia, research and conservation attention for podocnemidid turtles has focused primarily on the larger species that are more heavily harvested and imperiled, such as Podocnemis expansa, Podocnemis lewyana, and Podocnemis unifilis (Portocarrero-Aya, 2008; Escalona et al., 2012; Páez et al., 2012; Forero-Medina et al., 2016). Recently, studies also have been published on Colombian populations of $P$. vogli related to nest predation and captive rearing of hatchlings (López et al., 2019a), hemoparasites (González et al., 2019), taxonomy and systematics (López et al., 2019b), anatomy of the digestive and respiratory systems (Hernández-Henao et al., 2019), genetics (Silva-Galvis \& Ortiz-Moreno, 2019), biometry, and comparative pholidosis (Antelo, 2019). However, in recent decades there have been no publications focused on habitat use or demographics of this turtle species in Colombia.

Podocnemis vogli is restricted to the Orinoco drainage of Venezuela and Colombia (Ramo, 1982; Rueda-Almonacid et al., 2007; Portocarrero-Aya, 2008), with its area of occupation in Colombia covering only $304 \mathrm{~km}^{2}$ (Forero-Medina et al., 2014). According to Rueda-Almonacid et al. (2007) and Portocarrero-Aya (2008), the species is thought to not inhabit large rivers, instead occupying smaller, shallower bodies of water, "preferring" turbid waters with clay or mud bottoms and little aquatic vegetation. In the llanos of the Colombian Orinoco, the species was been described as principally using lentic habitats such as lagoons, backwaters, ponds, channels, and other wetland habitats (Morales-Betancourt et al., 2012a). 
At the national level, P. vogli is classified in Colombia as Least Concern (LC) based upon its apparent abundance (MoralesBetancourt et al., 2015). However, it is possible that population sizes are declining in some places due to increased harvest that represent a replacement phenomenon, as hunters shift their attention away from more depleted podocnemidid species such as P. expansa and P. unifilis (Morales-Betancourt et al., 2012a; Martínez-Callejas et al., 2015).

The establishment of a demographic baseline on abundance, age/size structure, sex ratios, and habitat use for $P$. vogli populations that have not suffered substantial harvest or habitat degradation are vital as a reference to guide management efforts for more impacted populations (Rhodin et al., 2018). Given that the Bojonawi Private Nature Reserve (BPNR) is relatively well conserved and protected, our goals were to document these aspects of its $P$. vogli population during the reproductive season, which allowed us to evaluate as well the minimum size of sexual maturity in females and document which secondary sexual characteristics are most useful for sexing subadult and adult individuals. We expected to find differences in the proportions of size classes and genders of $P$. vogli among macrohabitats, given that during the reproductive season females of species in the Family Podocnemididae tend to disperse to areas appropriate for nesting. We also expected to find differences among capture methods, because every capture method suffers from some particular biases related to the size and/or sex of the animals that are captured.

\section{MATERIALS AND METHODS}

\section{Study Site}

This study was conducted from 6 January to 6 April during the 2017 reproductive season in the floodplain of the Orinoco River in the BPNR within the buffer zone of the Tuparro National Park and UNESCO Biosphere Reserve (Fig. 1). The BPNR is located $15 \mathrm{~km}$ southwest of the city of Puerto Carreño (Vichada department, Colombia) at an elevation of 51 masl $\left(6.09799^{\circ} \mathrm{N}\right.$, $67.48321^{\circ} \mathrm{W}$ ). The region has a unimodal rainfall regimen, with a dry season extending from December to March. The mean annual temperature is $28^{\circ} \mathrm{C}$ and the mean annual precipitation is 2200 $\mathrm{mm}$ (Fundación Omacha, 2020). The BPNR is located along the Orinoco River and is mainly composed of savannah grassland, rocky outcroppings of the Guiana Shield, "morichales" (riparian vegetation dominated by the Moriche palm, Mauritia flexuosa), and clear and white-water channels draining seasonally flooded forests. We chose to focus field work during the reproductive season to be able to detect the presence of oviductal eggs within the reproductive tracts of $P$. vogli females.
We selected three different aquatic macrohabitats for this study: the main channel of the Orinoco River, the El Pañuelo lagoon, and a small tributary channel to the Orinoco River, the El Tesoro channel; the mean linear distance between the sites was $1.55 \mathrm{~km}(\mathrm{SD}=1.31$; Fig. 1 ). The river and lagoon habitats were wide (average of $1218 \mathrm{~m}$ and $157 \mathrm{~m}$, respectively), with warm waters of low transparency. In contrast, the channel was narrow (with an average width of $5.6 \mathrm{~m}$ ), with considerable vegetative cover and lower water temperatures (Gómez, 2018; Parra-Henao et al., 2019). All macrohabitats have been shown to differ in their physiochemical characteristics, sedimentation levels, nutrient contents, current flow, water transparency, and depth (Lasso et al., 2014).

\section{Capture methods}

To maximize capture rates, we used three capture methods (funnel traps, trammel nets, and manual capture), following the recommendations for working with freshwater turtles of De la Ossa et al. (2012). Because of the specific conditions in each macrohabitat during the reproductive season, it was only possible to sample them in a standardized manner (using funnel traps); for this reason, all statistical comparisons of macrohabitats are based solely on these data. We made a total of three sampling periods in each of the three macrohabitats, with five days of capturing effort in each sampling period and a two-week time interval between the start of each period per macrohabitat. In each sampling period, we installed 15 funnel traps; nine were double funnel traps (five with $0.8 \mathrm{~m}$ diameter hoops and $1.5 \mathrm{~m}$ in length, four with $0.38 \mathrm{~m}$ diameter hoops and $1.6 \mathrm{~m}$ in length) and six were single funnel traps (with $0.8 \mathrm{~m}$ diameter hoops and $1.05 \mathrm{~m}$ in length). We set the traps in shallow locations with little current near basking sites. We checked the traps three times daily (09:00, 15:00, and 21:00 h). We used three different types of bait: 10 traps were baited with fish, usually guabina (Hoplias malabaricus) and corn (Zea mays), and five traps were baited with corn and banana (Musa paradisiaca). In addition, when possible, we placed in all traps a raceme of leaves of "chigo" (Campsiandra comosa). Total funnel trap sampling effort (16200 trap-h) was standardized equally among macrohabitats: $120 \mathrm{~h}$ (five days) * 3 (sampling periods) $* 15$ (traps) $=5400$ trap $-\mathrm{h} /$ macrohabitat .

After setting or checking the traps, we focused on the other two capture methods. When turtles were visually detected (between 09:00 and 23:00 h), manual capture was attempted. In the El Pañuelo lagoon, manual capture was conducted in shallow water accessible from the shoreline or from a small boat. In the El Tesoro channel, we also manually captured individuals encountered while snorkeling. In the Orinoco River it was not possible to use this method due to the depth, current, 


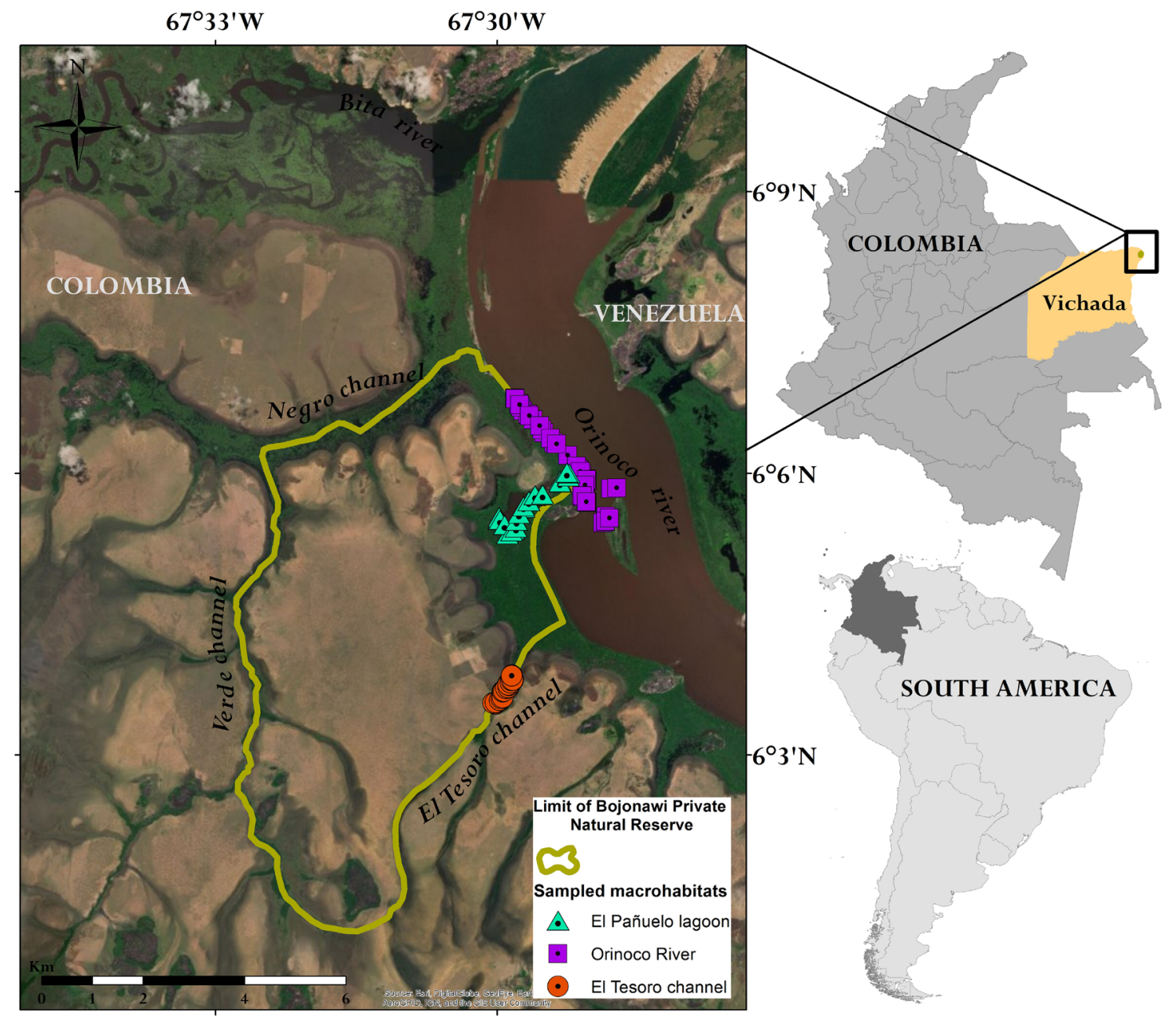

Figura 1. Ubicación de la Reserva Natural Privada Bojonawi, indicando los tres macrohábitats estudiados: Río Orinoco (púrpura), laguna El Pañuelo (azul) y canal El Tesoro (naranja). Los puntos indican la ubicación de las trampas tipo embudo durante los tres períodos de muestreo.

Figure 1. Location of the Bojonawi Private Nature Reserve, indicating the three macrohabitats studied: Río Orinoco (purple), the El Pañuelo lagoon (blue) and the El Tesoro channel (orange). The points indicate the locations of the funnel traps during the three sampling periods.

and turbidity of the water. The effort for this method was not standardized; of a total of 23 person-h of searching, only $4 \mathrm{~h}$ occurred in the El Pañuelo lagoon vs. $19 \mathrm{~h}$ in the Tesoro channel.

Capturing turtles with the trammel net was only possible in the lagoon macrohabitat, because in the other two macrohabitats the lead weights of the net could not settle on the bottom evenly, providing the turtles a means of escape. Prior to passing the trammel net (mesh size of $5 \mathrm{~cm}$, net size of $80 \mathrm{~m}$ wide X $5 \mathrm{~m}$ high) the site to be netted was baited by submerging in the area a mix of dry dog food and ground corn. In total, we conducted 15 passes in appropriate areas (of moderate depth, with few submerged objects), for a total effort of 6 person-h.

\section{Measuring and marking individuals}

All captured individuals were marked, weighed, measured, sexed, and photographed prior to their release at the capture location. Turtles were marked by cutting notches on marginal scutes using the modification of the Cagle (1939) system proposed by Rueda-Almonacid et al. (2007). Depending on the size of the individual, turtles were weighed using 1 or $20 \mathrm{~kg}$ dynamometer scales (Pesola, \pm 10 or $\pm 200 \mathrm{~g}$, respectively). The morphometric variables of straight-line carapace length (SCL), straight-line carapace width (SCW), maximum plastron length (MPL), and pre-cloacal tail length (PreCTL) were measured with digital $15 \mathrm{~cm}$ or $50 \mathrm{~cm}$ calipers (Mitutoyo and Haglof, $\pm 0.01 \mathrm{~mm}$ and $\pm 5 \mathrm{~mm}$, respectively). We also measured the length of the 
third nail (NL, $\pm 0.01 \mathrm{~mm}$ ) on the front left extremity, given that this trait has been reported to be useful for sexing some turtle species (Rueda-Almonacid et al., 2007).

\section{Sexing and estimating size at sexual maturity}

Individuals were sexed based on their body sizes, PreCTL, shape of the anal scale (with a " $V$ " shape typical of females vs. a " $U$ " shape typical of males, Morales-Betancourt et al., 2012b), and the presence of yellow spots on the head, especially in the snout area in males. Following the recommendations of Ramo (1982), males were considered sexually mature at body sizes of $13 \mathrm{~cm} \mathrm{SCL}$, and females at $20 \mathrm{~cm} \mathrm{SCL}$; these reproductive sizes were based upon an inspection of gross anatomy, including the size of follicles within the ovaries and the development of oviducts in females or the morphology of the testes and presence of sperm in the epididymis of males. In this study, we inspected the reproductive condition of captured females using a Bondway sonogram $(\mathrm{BW} 560 \mathrm{~V})$ by examining the inguinal region in individuals large enough to accommodate the probe, attempting to detect the presence of developing eggs. To facilitate comparison with previous studies of this species (Alarcón-Pardo, 1969; Ramo, 1982), we used the following five size classes and categories for the population structure analyses: juveniles $(\mathrm{SCL}<9 \mathrm{~cm})$, subadult females $(9 \mathrm{~cm} \leq \mathrm{SCL}<20 \mathrm{~cm})$, subadult males $(9 \mathrm{~cm} \leq$ $\mathrm{SCL}<13 \mathrm{~cm}$ ), adult females $(\geq 20 \mathrm{~cm})$ and adult males $(\geq 13 \mathrm{~cm})$.

\section{Statistical analyses}

The overall relative abundances in the three macrohabitats were estimated as the number of captures per trap-h, using the standardized funnel trap data. We tested for differences in the number of individuals captured during each sampling period in each macrohabitat, using a heterogeneity $X^{2}$ to see if the observed abundances differed from a random pattern. We also used a chi-squared goodness-of-fit test to inspect for equal sex ratios ( 1 우:1 $\left.{ }^{\top}\right)$. Differences among body sizes between macrohabitats were inspected using an ANOVA on the SCL data. A multivariate MANOVA was used to examine which morphometric variables differed between sexes and a linear discriminant analysis was used to determine which variables were most useful for sexing subadult and adults.

We examined movements within the study site based on the data from the recaptured turtles using Advance ArcMap version 10.2.2.3552 of the ArcGis software (version 10.2.2). All analyses were conducted using RStudio (version 1.0.153, RStudio Inc., 2017) by the R Project software (version 3.4.0, R Development Core Team, 2017).

\section{RESULTS}

With the three capture methods, we obtained a total of 149 P. vogli individuals, but only recaptured 11. Of these turtles, only three were juveniles, three were sub-adult males, 34 were subadult females, 67 were adult males and 42 were adult females. The number of individuals captured varied among methods and macrohabitats (Table 1). During the day, we frequently observed $P$. vogli individuals basking or floating on the surface in all three macrohabitats.

We captured 81 of the 149 individuals using the standardized funnel trap method, as well as obtained eight of the 11 recaptures in these traps. Relative abundances based upon these data was highest in the El Pañuelo lagoon ( 0.007 individuals/trap-h), and lower but comparable in the Orinoco River ( 0.005 individuals/ trap-h) and El Tesoro channel ( 0.004 individuals/trap-h). Of the total captures obtained using funnel traps, $19.1 \%$ were captured during the first sampling period, $38.2 \%$ during the second period, and $42.7 \%$ during the last sampling period. These differences did not differ significantly from a null hypothesis of equal captured proportions in each period $\left(X_{2}^{2}=4.74, P=0.09\right)$. We found no differences in the size distributions of individuals captured with the funnel traps in the three macrohabitats (ANOVA, SCL, $F_{2,80}=$ $0.251, P=0.778)$. Capture success with the funnel trap method was greatest between 09:00-21:00 h, representing $76.4 \%$ of all captures vs. only $23.6 \%$ in the $21: 00-09: 00$ interval.

Using the hand-capture method, we captured 28 and recaptured two individuals in the two macrohabitats where this technique could be implemented (lagoon and channel), for a success rate of 1.3 individuals/h. We did not inspect statistically for differences with this method between those two macrohabitats due to very different sampling efforts among them (4 $\mathrm{h}$ vs $19 \mathrm{~h}$ ). With the trammel net in the El Pañuelo lagoon we captured 40 turtles, plus one recaptured individual that had been initially trapped in a funnel trap, for a success rate of 6.83 individuals/h.

Sex ratios differed among macrohabitats (heterogeneity $X_{2}^{2}=$ 8.922; $P<0.01$ ), being unbiased in the El Tesoro channel (1 $\bigcirc: 1{ }^{1}$; $X_{1}^{2}=0 ; P=1.0$ ), significantly male biased in the Orinoco River (19 : $2.60^{2} ; X_{1}^{2}=4.84 ; P<0.01$ ), and significantly female biased in the El Pañuelo lagoon $\left(19: 0.5 \delta^{\lambda} ; X_{1}^{2}=4.33 ; P<0.01\right)$, yielding an overall balanced sex ratio for the population over all three macrohabitats ( 1 : $: 1.07 \delta^{2} ; X_{2}^{2}=0 ; P=1.0$ ). Taken as a whole, there was significant sexual dimorphism between the sexes (subadult and adult females vs. subadult and adult males; HOTELLING MANOVA test: $F_{1,145}=19.262 ; P<0.001$ ), with females being 
Tabla 1. Eficiencia de captura para $P$. vogli por clase de tamaño y sexo usando cada metodología en cada uno de los tres macrohábitats. El esfuerzo de muestreo para cada método fue: red de pesca de trasmallo: 6 h-personas; captura manual: 23 h-personas; trampas tipo embudo: 5400 h-trampa. El porcentaje de captura es el número de individuos capturados con el método / el número total de individuos capturados* 100.

Table 1. Capture efficiency for $P$. vogli by size class and sex using each method in each of the three macrohabitats. Sampling effort for each method was: trammel fishing net: 6 person-h; manual capture: 23 person-h; funnel traps: 5,400 trap-h. Catch percentage is the number of individuals captured with the method/the total number of individuals captured * 100 .

\begin{tabular}{|c|c|c|c|c|}
\hline & & $\begin{array}{c}\text { Funnel } \\
\text { traps }\end{array}$ & $\begin{array}{l}\text { Manual } \\
\text { capture }\end{array}$ & $\begin{array}{c}\text { Trammel } \\
\text { nets }\end{array}$ \\
\hline \multirow{6}{*}{$\begin{array}{l}\text { El Pañuelo } \\
\text { Lagoon }\end{array}$} & Adult males & 10 & 1 & 22 \\
\hline & Adult females & 14 & 0 & 9 \\
\hline & Subadult males & 1 & 0 & 0 \\
\hline & Subadult females & 9 & 4 & 9 \\
\hline & Juveniles & 0 & 2 & 0 \\
\hline & Subtotal & 34 & 7 & 40 \\
\hline \multirow{6}{*}{$\begin{array}{c}\text { El Tesoro } \\
\text { Channel }\end{array}$} & Adult males & 11 & 6 & 0 \\
\hline & Adult females & 7 & 7 & 0 \\
\hline & Subadult males & 0 & 1 & 0 \\
\hline & Subadult females & 4 & 6 & 0 \\
\hline & Juveniles & 0 & 1 & 0 \\
\hline & Subtotal & 22 & 21 & 0 \\
\hline \multirow{6}{*}{ Orinoco River } & Adult males & 17 & 0 & 0 \\
\hline & Adult females & 5 & 0 & 0 \\
\hline & Subadult males & 1 & 0 & 0 \\
\hline & Subadult females & 2 & 0 & 0 \\
\hline & Juveniles & 0 & 0 & 0 \\
\hline & Subtotal & 25 & 0 & 0 \\
\hline \multicolumn{2}{|l|}{ Total captures } & 81 & 28 & 40 \\
\hline \multicolumn{2}{|c|}{$\%$ Total captures } & 55.6 & 18.7 & 25.7 \\
\hline \multicolumn{2}{|c|}{ Abundance/sampling effort (h) } & 0.0055 & 1.30 & 6.83 \\
\hline
\end{tabular}

heavier, larger and wider (SCL, MPL, SCW) than males, with a maximum SCL of $30 \mathrm{~cm}$ and body weight of $3 \mathrm{~kg}$ (Table 2, Fig. 2). The original variables that best distinguished the sexes for all sizes (except juveniles) were PreCTL, NL, MPL, and SCL (Linear discriminant analysis: $\mathrm{LD} 1=95.5 \%$; $\mathrm{LD}_{2}=4.5 \%$; Table 3 ).
Tabla 2. Estadística descriptiva de las variables morfométricas cuantificadas para los individuos no juveniles de $P$. vogli capturados durante el estudio.

Table 2. Descriptive statistics for the morphometric variables quantified for the nonjuveniles $P$. vogli individuals captured during the study.

\begin{tabular}{|c|c|c|c|c|}
\hline \multirow[t]{2}{*}{ Variable } & \multicolumn{2}{|c|}{$\begin{array}{l}\text { Sub-adult and adult } \\
\text { males }\end{array}$} & \multicolumn{2}{|c|}{$\begin{array}{l}\text { Sub-adult and adult } \\
\text { females }\end{array}$} \\
\hline & Mean \pm SD & Range & Mean \pm SD & Range \\
\hline Weight (g) & $742.5 \pm 490$ & $250-2800$ & $1438.6 \pm 835$ & $110-3000$ \\
\hline $\begin{array}{l}\text { Straight-line } \\
\text { carapace } \\
\text { length }(\mathrm{cm})\end{array}$ & $17.6 \pm 3.5$ & $12.5-27.8$ & $21.7 \pm 5.7$ & $9.15-30$ \\
\hline $\begin{array}{c}\text { Maximum } \\
\text { plastron } \\
\text { length }(\mathrm{cm})\end{array}$ & $15.7 \pm 3.2$ & $10.4-24.9$ & $19.8 \pm 5.2$ & $8.36-26.7$ \\
\hline $\begin{array}{l}\text { Straight-line } \\
\text { carapace } \\
\text { width }(\mathrm{cm})\end{array}$ & $13.4 \pm 2.5$ & $9.13-20.5$ & $16.1 \pm 4$ & $7.3-22.5$ \\
\hline $\begin{array}{l}\text { Pre-cloacal } \\
\text { tail length } \\
\text { (cm) }\end{array}$ & $3.2 \pm 0.7$ & $0.75-5.05$ & $2.7 \pm 1.1$ & $0.58-4.5$ \\
\hline $\begin{array}{l}\text { Nail length } \\
\text { (cm) }\end{array}$ & $0.77 \pm 0.3$ & $0.59-1.29$ & $0.96 \pm 0.2$ & $0.55-1.34$ \\
\hline
\end{tabular}

The minimum body size for females where it was possible to insert the sonogram probe into the inguinal region was $22 \mathrm{~cm}$ SCL. From a sample of 27 females with a CL larger than $22 \mathrm{~cm}$ SCL, nine were found to have oviductal eggs in differing stages of calcification, with the last such individual recorded near the end of February. The smallest female detected to carry oviductal eggs was $24.1 \mathrm{~cm}$ SCL.

The mean linear distance moved by the recaptured individuals was $380 \mathrm{~m}$ (range $34-1602 \mathrm{~m}$ ). Males ( $\mathrm{n}=9$ ) moved approximately twice as far as females $(n=6)$, with a male mean linear distance $=$ $468 \mathrm{~m}$ (range: 34 - 1602) and a female mean linear distance of 226 $m$ (range: 92 - 544). Given the limited sample sizes, we did not compare these data statistically. 


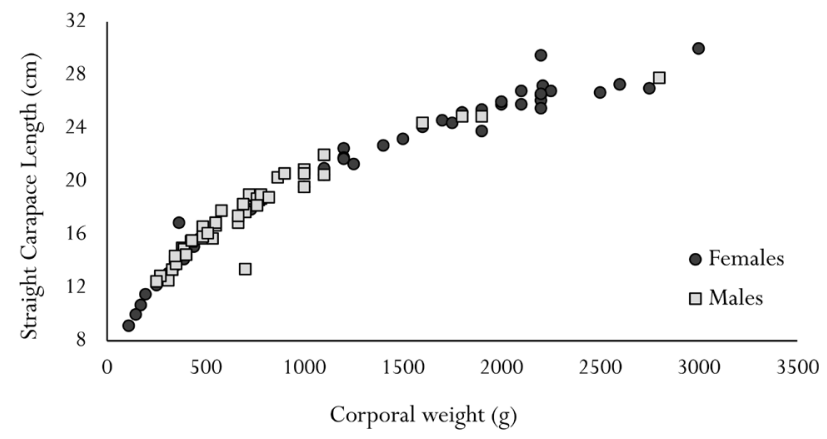

Figura 2. Relación entre la longitud recta del caparazón y el peso corporal entre machos (cuadrados) y hembras (círculos). Las hembras adultas (SCL > $20 \mathrm{~cm}$ ) alcanzan tamaños y pesos mayores que los machos adultos $(S C L>13 \mathrm{~cm}) t$.

Figure 2. Relationship between Straight-line carapace length and Body weight for males (squares) and females (circles). Adult females $(\mathrm{SCL}>20 \mathrm{~cm}$ ) attain larger sizes and weights than adult males $(S C L>13 \mathrm{~cm})$.

\section{DISCUSSION}

During the 2017 reproductive season at the BPNR, P. vogli did not show a marked segregation in terms of macrohabitat use, with both sexes and most size classes occupying each macrohabitat type sampled, including the main channel of the Orinoco River. Other studies with this species have reported it to exhibit a preference for lentic habitats, such as lagoons and shallow channels (Alarcón-Pardo, 1969; Ramo, 1982). This discrepancy between previous characterizations and our results may be related to diverse causes, including the time of year when field work was conducted (De Souza et al., 2013; Eisemberg et al., 2016; Ponce De Leão et al., 2019; Alzate-Estrada et al., 2020), the capture methods employed (Bernhard \& Vogt, 2012; Bernardes et al., 2014; Portelinha et al., 2014; Parra-Henao et al., 2019), and the effort invested in sampling different types of habitat with different methods (Bernhard, 2010; Páez et al., 2015). Due to our use of a standardized method (funnel traps) appropriate for all three of the macrohabitat types we sampled, and the comparable sampling effort in each, we were able to show that the relative abundance of $P$. vogli in the river was comparable to the relative abundance of individuals in the lentic channel macrohabitat. Studies that rely on other sampling methods were incapable of detecting P. vogli in lotic habitats, such as manual capture, could give an erroneous impression that the species avoids large rivers (Rueda-Almonacid et al., 2007; Morales-Betancourt et al., 2012a). The fact that previous studies have not reported use of river habitat by $P$. vogli also might be related to geographic variation in habitat preferences. We worked in the Orinoco River floodplain, while previous studies with this species were conducted in llanos
Tabla 3. Análisis discriminante lineal de las variables morfométricas para machos y hembras (subadultos y adultos) capturados en las trampas tipo embudo. LD1 explicó el 95.5\% de la variación total y las variables que más se cargaron en este eje fueron: Longitud precloacal de la cola, Longitud de la uña y Longitud máxima del plastrón. La variable que más cambió de LD1 y LD2 fue la longitud del caparazón de línea recta.

Table 3. Linear discriminant analysis of the morphometric variables for males and females (subadults and adults) captured in the funnel traps. LD1 explained $95.5 \%$ of the total variation, with the variables loading most heavily on this axis being Pre-cloacal tail length, Nail length, and Maximum plastron length. The variable that changed the most from LD1 and LD2 was Straight-line carapace length.

\section{$\begin{array}{lll}\text { Discriminant axes } & \text { LD1 } & \text { LD2 }\end{array}$}

\begin{tabular}{lcc}
\hline Proportion of variance & $95.5 \%$ & $4.5 \%$ \\
Weight & -0.0011139 & -0.0034736 \\
Straight-line carapace length & 0.2229578 & 0.4691173 \\
Maximum plastron length & -1.0470836 & 0.2972779 \\
Straight-line carapace width & 0.6038456 & -0.1849690 \\
Pre-cloacal tail length & 2.2070274 & 0.0796968 \\
Nail length & 1.3405209 & -0.1226703 \\
\hline
\end{tabular}

piedmont or in seasonally flooded pluvial plains (Alarcón-Pardo, 1969; Ramo, 1982) where P. vogli individuals may indeed not enter larger water bodies. Regardless, our study is the first to show that in some locations $P$. vogli individuals may be present in substantial numbers in large riverine habitats. Unfortunately, the low number of recaptures in this study precluded the estimation of detectabilites for each sex and/or size class to rigorously estimate actual densities in each macrohabitat, instead of having to compare estimates of relative abundances.

Sex ratios in turtle populations may vary on a local scale due to differences in habitat preferences of males and females (Portelinha et al., 2014; Viloria \& Forti, 2015) and differences in mortality rates of each sex in different habitat types (FachínTerán \% Vogt, 2004; Folt et al., 2016). In our study, we documented sex ratio skews in favor of males in the river macrohabitat and females in the lagoon macrohabitat. One possible explanation for this is the proximity of suitable nesting habitat (savannah grassland, Barrio-Amorós \& Narbaiza, 2008) along the margins of the lagoon where females were found in greater numbers, combined with a tendency in males to be more vagile in general, as has been shown in other podocnemidid species (Fachín-Terán et al., 2006; Bernhard, 2010; Alzate-Estrada et al., 2020). Our 
results illustrate how caution should be used in interpreting data on sex ratios that are collected in a few habitat types over short sampling periods; we have shown sex ratios in P. vogli to vary spatially over short distances and more long-term studies also might show that sex ratios in each macrohabitat may vary temporally.

Funnel traps successfully captured individuals of most size classes in all three macrohabitats, although juveniles were dramatically less commonly trapped than individuals larger than $9 \mathrm{~cm}$. In contrast, the trammel net method was far more efficient in the macrohabitat (lagoon) where it was possible to use. In only six hours of sampling with this method, we captured roughly $50 \%$ of the total number of individuals sampled during 16,200 trap-h of effort with the funnel traps in all three macrohabitats. But the trammel net method had a significant bias, because no juveniles and fewer subadults than adults were obtained.

Manual capture of individuals that were detected visually also was a viable method in water bodies that were clear and with slow currents. While the results obtained with all methods indicate that $P$. vogli is primarily active during the day (71.9\% of captures), through use of the manual capture method we also documented for the first time that nocturnal foraging in P. vogli occurs.

It was possible to confidently distinguish between sex and sub-adult and adult individuals (SCL $>9 \mathrm{~cm}$ ) based on secondary sexual characteristics, with PreCTL the most reliable morphometric variable (males have longer PreCTLs). This agrees with Alarcón-Pardo (1969) and Ramo (1982), where males were reported to have thicker and longer tails, up to double the length of females with comparable body sizes. This character also has been shown to be useful for sexing other podocnemidid species (Pritchard \& Trebbau, 1984; Iverson, 1995; Bernhard, 2010). The second most useful morphometric character to distinguish sexes in this study was NL, but only for adult individuals. This trait also has been used to sex turtles belonging to genera in the Family Emydidae, where males have longer nails on their third digits as well (Rueda-Almonacid et al., 2007). The longer nails apparently function to help males grasp females during courtship and mating (Bernhard et al., 2012; Ceballos et al., 2012; Escalona et al., 2012).

Although we may not have been able to detect reproductively active females with $\mathrm{SCL}<22 \mathrm{~cm}$ (due to the size limitations imposed by our sonogram probe), the smallest female we detected with oviductal eggs using the sonogram had a SCL = $24 \mathrm{~cm}$, which agrees with reports from other areas in Colombia and Venezuela (Alarcón-Pardo, 1969; Ramo, 1982; Pritchard \& Trebbau, 1984). In terms of the phenology of the reproductive season, Alarcón-Pardo (1969) and Portocarrero-Aya (2008) reported that $P$. vogli in Colombia nest from November to January, while we documented oviductal females using the sonogram in February, which agrees with the dates for nesting reported by Ramo (1982) for Apuré, Venezuela.

The few recaptures during our relatively short study revealed only limited local movements of individuals, with no movements documented between macrohabitats. However, we did document one case of a long-distance movement involving a change in macrohabitat with our capture of the female marked during a previous study (in 2015 in the Bita River, $6.15669^{\circ} \mathrm{N}, 67.50761^{\circ} \mathrm{W}$; Morales-Betancourt \& Lasso, unpublished data), having dispersed $9.3 \mathrm{~km}$. Ramo (1982) also documented comparable movements by male $P$. vogli during the period of flooding in the rainy season in the Venezuelan llanos. Future more intensive mark-recapture efforts in our study site will probably reinforce and extend the results obtained during our three-month study indicating that P. vogli individuals are capable of moving substantial distances during their ontogeny, as has been shown in other podocnemidid species (Fachín-Terán et al., 2006; Bernhard, 2010; AlzateEstrada et al., 2020).

Acknowledgements.- Permission for collecting turtles was granted by Resolución 0524 of 27 May 2014 by the National Authority for Environmental Licenses to the Universidad de Antioquia. We thank the Grupo Herpetológico de Antioquia, the Instituto de Investigación de Recursos Biológicos Alexander von Humboldt, and the Fundación Omacha for their financial and logistic support of this study. We also thank the personnel of the Bojonawi Private Nature Reserve, and to Keisy Parra-Henao, Beyker Castañeda, Brayan Marín, Jacinto Terán, Alejandro Jaspe and Víctor Rico for their help and guidance during field work. We thank Brian Bock for suggestions on earlier versions of this manuscript and his help with the English version of the manuscript, and students and professors of the Universidad de Antioquia, especially Stiven Pérez Pulgarín, Viviana CartagenaOtálvaro, Diego Alzate-Estrada and Faidith Bracho for their assistance in preparing for field work and help with the statistical analyses.

\section{CITED LITERATURE}

Alzate-Estrada, D.A., V.P. Páez, V.M. Cartagena-Otálvaro \& B.C. Bock. 2020. Linear home range and seasonal movements of Podocnemis lewyana in the Magdalena River, Colombia. Copeia 108(1):29-38. 
Antelo, R. 2019. Biometría y folidosis comparada en jóvenes de tres especies del género Podocnemis (P. expansa, $P$. unifilis y $P$. vogli) de los llanos Orientales de Colombia. Pp. 52-71. In O.A. RodríguezFandiño, A.G. Cortés, J.A. Rodríguez-Pulido, W.J. Hernández, N.E. Matta Camacho, M.T. Nieto-Vera, M. Vargas-Ramírez, G.A. López, A.D. Jiménez \& R. Antelo (Eds.). El Galápago Sabanero: Estudios en Búsqueda de su Conservación. PAREX Resources and Dirección de Investigación Unitrópico, Yopal, Colombia.

Alarcón-Pardo, H. 1969. Contribución al conocimiento de la morfología, ecología, comportamiento y distribución geográfica de Podocnemis vogli, Testudinata (Pelomedusidae). Revista de la Academia Colombiana de Ciencias Exactas, Físicas y Naturales 13:303-329.

Barahona, R. \& J. López. 2015. Estructura poblacional de la tortuga blanca, Dermatemys mawii Gray (Testudines, Dermatemydidae), en la Laguna El Perú, Petén, Guatemala. Revista Científica de la Facultad de Ciencias Químicas y Farmacia 2:75-86.

Barrio-Amorós, C. \& I. Narbaiza. 2008. Turtles of the Venezuelan Estado Amazonas. Radiata 17:2-19.

Bernardes, V.C.D., C.R. Ferrara, R.C. Vogt \& L. Schneider. 2014. Abundance and population structure of Podocnemis erythrocephala (Testudines, Podocnemididae) in the Unini River. Amazonas. Chelonian Conservation and Biology 13:89-95.

Bernhard, R. 2010. Dinâmica populacional de Podocnemis erythrocephala, no rio Ayuanã, Amazonas, Brasil. Ph.D. Dissertation, Instituto Nacional de Pesquisas da Amazônia, Brasil.

Bernhard, R. \& R.C. Vogt. 2012. Population structure of the turtle Podocnemis erythrocephala in the Rio Negro Basin, Brazil. Herpetologica 68:491-504.

Bernhard, R., J. De la Ossa, R.C. Vogt, M.A. Morales-Betancourt \& C.A. Lasso. 2012. Podocnemis erythrocephala. Pp. 360-366. In V.P. Páez, M.A. Morales-Betancourt, C.A. Lasso, O.V. CastañoMora \& B.C. Bock (Eds.). V. Biología y Conservación de las Tortugas Continentales de Colombia, Serie Editorial Recursos Hidrobiológicos y Pesqueros Continentales de Colombia. Instituto de Investigación de Recursos Biológicos Alexander von Humboldt, Bogotá, Colombia.

Böhm, M., R. Williams, H.R. Bramhall, K.M. McMillan, A.D. Davidson, A. García-Aguayo, L.M. Bland, J. Bielby \& B. Collen. 2016. Correlates of extinction risk in squamate reptiles: the relative importance of biology, geography, threat and range sizes. Global Ecology and Biogeography 25:391-405.

Cagle, F.R. 1939. A system of marking turtles for future identification. Copeia 1939:170-173.

Ceballos, C. J. Iverson \& R. Bernhard. 2012. Podocnemis sextuberculata. Pp. 382-386. In V.P. Páez, M.A. Morales-Betancourt, C.A. Lasso, O.V. Castaño-Mora \& B.C. Bock (Eds.). V. Biología y Conservación de las Tortugas Continentales de Colombia, Serie Editorial Recursos Hidrobiológicos y Pesqueros Continentales de Colombia. Instituto de Investigación de Recursos Biológicos Alexander von Humboldt, Bogotá, Colombia.

De la Ossa, J., G. Cárdenas-Arévalo \& V.P. Páez. 2012. Métodos de campo para estudios demográficos. Pp. 171-186. In V.P. Páez, M.A. Morales-Betancourt, C.A. Lasso, O.V. Castaño-Mora \& B.C. Bock (Eds.). V. Biología y Conservación de las Tortugas Continentales de Colombia, Serie Editorial Recursos Hidrobiológicos y Pesqueros Continentales de Colombia. Instituto de Investigación de Recursos Biológicos Alexander von Humboldt, Bogota, Colombia.

De Souza Alcântara, A., D.F. Da Silva \& J.C.B. Pezzuti. 2013. Effects of the hydrological cycle and human settlements on the population status of Podocnemis unifilis (Testudines: Podocnemididae) in the Xingu River, Brazil. Chelonian Conservation and Biology 12:134142.

Eisemberg, C.C., S.J. Reynolds, K.A. Christian \& R.C. Vogt. 2016. Diet of Amazon river turtles (Podocnemididae): a review of the effects of body size, phylogeny, season and habitat. Zoology 120:92-100

Escalona, T., K. Conway-Gómez, M.A. Morales-Betancourt, F. Arbeláez \& R. Antelo. 2012. Podocnemis unifilis. Pp. 387-398. In V.P. Páez, M.A. Morales-Betancourt, C.A. Lasso, O.V. CastañoMora \& B.C. Bock (Eds.). V. Biología y Conservación de las Tortugas Continentales de Colombia, Serie Editorial Recursos Hidrobiológicos y Pesqueros Continentales de Colombia. Instituto de Investigación de Recursos Biológicos Alexander von Humboldt, Bogota, Colombia.

Fachín-Terán, A. \& R.C. Vogt. 2004. Estrutura populacional, tamanho e razão sexual de Podocnemis unifilis (Testudines, Podocnemididae) no rio Guaporé (RO), norte do Brasil. Phyllomedusa 3:29-42. 
Fachin-Terán, A., R.C. Vogt \& J.B. Thorbjarnarson. 2006. Seasonal movements of Podocnemis sextuberculata (Testudines: Podocnemididae) in the Mamirauá Sustainable Development Reserve, Amazonas, Brazil. Chelonian Conservation and Biology 5:18-24.

Folt, B., J.B. Jensen, A. Teare \& D. Rostal. 2016. Establishing reference demography for conservation: A case study of Macrochelys temminckii in Spring Creek, Georgia. Herpetological Monographs 30:21-33.

Forero-Medina, G., A.P. Yusti-Muñoz \& O.V. Castaño-Mora. 2014. Distribución geográfica de las tortugas continentales de Colombia y su representación en áreas protegidas. Acta Biológica Colombiana 19:415-426.

Forero-Medina, G., V.P. Páez, M.F. Garcés-Restrepo, J.L. Carr, A. Giraldo \& M, Vargas-Ramírez. 2016. Research and conservation priorities for tortoises and freshwater turtles of Colombia. Tropical Conservation Science 9:1-14.

Fundación Omacha. 2020. Reserva Natural Privada Bojonawi.http:// omacha.org/reserva-natural-bojonawi/. Bogotá, Colombia. [Accessed in July 2020].

Gallego-García, N. \& O.V. Castaño-Mora. 2008. Ecology and status of the Magdalena River turtle, Podocnemis lewyana, a Colombian endemic. Chelonian Conservation and Biology 7:37-44.

Gómez, M.T. 2018. Caracterización del uso del hábitat y actividad de tres especies de tortugas acuáticas (Podocnemididae) durante la estación seca en la Reserva Natural Privada Bojonawi (RNPB), Vichada, Colombia. Undergraduate thesis. Universidad de Antioquia, Colombia.

González-Zárate, A., O. Montenegro, O.V. Castaño-Mora \& M. Vargas-Ramírez. 2014. Abundancia, estructura poblacional y conservación de Podocnemis lewyana (Podocnemididae) en el río Prado, Colombia. Acta Biológica Colombiana 19:351-361.

González, L.P., N.E. Matta, A.D. Jiménez \& O.A. Rodríguez. 2019. Los hemoparásitos del galápago sabanero (Podocnemis vogli) (Testudines: Podocnemididae). Pp. 72-86. In O. A. RodríguezFandiño, A.G. Cortés, J.A. Rodríguez-Pulido, W.J. Hernández, N.E. Matta Camacho, M.T. Nieto-Vera, M. Vargas-Ramírez, G.A. López, A.D. Jiménez \& R. Antelo (Eds.). El Galápago Sabanero: Estudios en Búsqueda de su Conservación. PAREX Resources and Dirección de Investigación Unitrópico, Yopal, Colombia.
Hernández-Henao,W.J.,J.A.Astwood-Romero,M.T.Nieto-Vera\&J.A. Rodríguez-Pulido. 2019. Anatomía macroscópica y microscópica de los sistemas digestivo y respiratorio del galápago sabanero Podocnemis vogli Müller, 1935 (Testudines:Podocnemididae). Pp. 112-135. In O. A. Rodríguez-Fandiño, A.G. Cortés, J.A. RodríguezPulido, W.J. Hernández, N.E. Matta Camacho, M.T. Nieto-Vera, M. Vargas-Ramírez, G.A. López, A.D. Jiménez \& R. Antelo. El Galápago Sabanero: Estudios en Búsqueda de su Conservación. PAREX Resources and Dirección de Investigación Unitrópico, Yopal, Colombia.

Heppell, S.S. 1998. Application of life-history theory and population model analysis to turtle conservation. Copeia 1998:367-375.

Iverson, J.B. 1995. Podocnemis lewyana. Catalogue of American Amphibians and Reptiles 605:1-3.

Lasso, C.A., A. Rial, G. Colonnello, A. Machado-Allison \& F. Trujillo. 2014. XI. Humedales de la Orinoquía (Colombia-Venezuela). Serie Editorial Recursos Hidrobiológicos y Pesqueros Continentales de Colombia (Colombia-Venezuela). Instituto de Investigación de Recursos Biológicos Alexander von Humboldt, Bogotá, Colombia.

López, G.A., J.I. Rondón, E. Martínez, H. Moya \& O.A. Rodríguez. 2019a. Depredación de nidos y neonatos protegidos de Podocnemis vogli (sabanas inundables del Casanare). Pp. 42-51. In O. A. Rodríguez-Fandiño, A.G. Cortés, J.A. Rodríguez-Pulido, W.J. Hernández, N.E. Matta Camacho, M.T. Nieto-Vera, M. Vargas-Ramírez, G.A. López, A.D. Jiménez \& R. Antelo (Eds.). El Galápago Sabanero: Estudios en Búsqueda de su Conservación. PAREX Resources and Dirección de Investigación Unitrópico, Yopal, Colombia.

López, G.A., J.I. Rondón, M. Vargas-Ramírez \& O.A. Rodríguez. 2019b. Taxonomía y sistemática del galápago sabanero. Pp. 87-95. In O. A. Rodríguez-Fandiño, A.G. Cortés, J.A. Rodríguez-Pulido, W.J. Hernández, N.E. Matta Camacho, M.T. Nieto-Vera, M. Vargas-Ramírez, G.A. López, A.D. Jiménez \& R. Antelo (Eds.). El Galápago Sabanero: Estudios en Búsqueda de su Conservación. PAREX Resources and Dirección de Investigación Unitrópico, Yopal, Colombia.

Martínez-Callejas, S.J., C. Durán-Prieto, V.P. Páez, F. Trujillo \& A. Trujillo-Pérez. 2015. Podocnemis expansa (Müller 1935). Pp. 132136. In M.A. Morales-Betancourt, C.A. Lasso, V.P. Páez \& B.C. Bock (Eds.). Libro Rojo de Reptiles de Colombia. Instituto de Investigación de Recursos Biológicos Alexander von Humboldt, Bogotá, Colombia. 
Miorando, P.S., G.H. Rebêlo, M.T. Pignati \& J.C.B. Pezzuti. 2013. Effects of community-based management on Amazon river turtles: a case study of Podocnemis sextuberculata in the lower Amazon floodplain, Pará, Brazil. Chelonian Conservation and Biology 12:143-150.

Morales-Betancourt, M.A., C.A. Lasso \& F. Trujillo. 2012 a. Podocnemis vogli (Müller 1935). Pp. 399-403. In V.P. Páez, M.A. Morales-Betancourt, C.A. Lasso, O.V. Castaño-Mora \& B.C. Bock (Eds.). V. Biología y Conservación de las Tortugas Continentales de Colombia, Serie Editorial Recursos Hidrobiológicos y Pesqueros Continentales de Colombia. Instituto de Investigación de Recursos Biológicos Alexander von Humboldt, Bogota, Colombia.

Morales-Betancourt, M.A., C.A. Lasso, F. Trujillo, J. De La Ossa, G. Forero-Medina \& V.P. Páez. 2012b. Amenazas a las poblaciones de tortugas continentales de Colombia. Pp. 453-492. In V.P. Páez, M.A. Morales-Betancourt, C.A. Lasso, O.V. CastañoMora \& B.C. Bock (Eds.). V. Biología y Conservación de las Tortugas Continentales de Colombia, Serie Editorial Recursos Hidrobiológicos y Pesqueros Continentales de Colombia. Instituto de Investigación de Recursos Biológicos Alexander von Humboldt, Bogota, Colombia.

Morales-Betancourt M.A., C.A. Lasso, V.P. Páez \& B.C. Bock (Eds.). 2015. Libro Rojo de Reptiles de Colombia. Instituto de Investigación de Recursos Biológicos Alexander von Humboldt, Bogotá, Colombia.

Naveda-Rodríguez, A., R. Cueva \& G. Zapata-Ríos. 2018. Space use of Yellow-Spotted River Turtles (Podocnemis unifilis) in Yasuni National Park, Ecuador. Chelonian Conservation and Biology 17:37-43.

Páez, V.P., A. Restrepo, M. Vargas-Ramírez, B.C. Bock \& N. GallegoGarcía. 2012. Podocnemis lewyana. Pp. 375-381. In V.P. Páez, M.A. Morales-Betancourt, C.A. Lasso, O.V. Castaño-Mora \& B.C. Bock (Eds.). V. Biología y Conservación de las Tortugas Continentales de Colombia, Serie Editorial Recursos Hidrobiológicos y Pesqueros Continentales de Colombia. Instituto de Investigación de Recursos Biológicos Alexander von Humboldt, Bogota, Colombia.

Páez, V.P., B.C. Bock, P.A. Espinal-García, B.H. Rendón-Valencia, D.A. Alzate-Estrada, V.M. Cartagena-Otálvaro \& S.S. Heppell. 2015. Life history and demographic characteristics of the Magdalena River turtle (Podocnemis lewyana): implications for management. Copeia 103:1058-1074.
Parra-Henao, K.D., V.P. Páez, M.A. Morales-Betancourt \&C.A. Lasso. 2019. A pilot study of habitat use and population characteristics of the big-headed Amazon river turtle, Peltocephalus dumerilianus (Schweigger 1812), during the dry season in the Bojonawi Nature Reserve, Vichada, Colombia. Herpetology Notes 12:1113-1120.

Ponce De Leão, S., S. Famelli \& R.C. Vogt. 2019. Home range of Yellow-Spotted Amazon river turtles (Podocnemis unifilis) (Testudines: Podocnemididae) in the Trombetas River Biological Reserve, Pará, Brazil. Chelonian Conservation and Biology 18:1018.

Portelinha, T.C., A. Malvasio, C.I. Piña \& J. Bertoluci. 2014. Population structure of Podocnemis expansa (Testudines: Podocnemididae) in southern Brazilian Amazon. Copeia 2014:707-715.

Portocarrero-Aya, M. 2008. Tortugas del género Podocnemis. Especies amenazadas en la Reserva de Biósfera El Tuparro. Pp. 77-89. In F. Trujillo, M. Portocarrero-Aya \& C. Gómez (Eds.) Plan de Manejo y Conservación de Especies Amenazadas en la Reserva de Biósfera El Tuparro: Delfines de Río, Manatíes, Nutrias, Jaguares y Tortugas del Género Podocnemis. Proyecto Pijiwi Orinoko (Fundación Omacha-Fundación Horizonte Verde), Bogota, Colombia.

Pritchard, P. \& P. Trebbau, P. 1984. The Turtles of Venezuela. Society for the Study of Amphibians and Reptiles, Athens, Ohio.

Ramo, C. 1982. Biología del galápago (Podocnemis vogli Müller, 1935) en el Hato "El Frio", llanos de Apure (Venezuela). Doñana. Acta Vertebrata 9:1-161.

Ripple, W.J., C. Wolf, T.M. Newsome, M. Hoffman, A.J. Wirsing \& D.J. McCauley. 2017. Extintion risk is most acute for the world's largest and smallest vertebrates. Proceedings of the National Academy of Sciences 114:10678-10683.

Rhodin, A.G., C.B. Stanford, P.P. van Dijk, C. Eisemberg, L. Luiselli, R.A. Mittermeier, R. Hudson, B.D. Horne, E.V. Goode, G. Kuchling, A. Walde, E.H.W. Baard, K.H. Berry, A. Bertolero, T.E.G. Blanck, R. Bour, K.A. Buhlmann, L.J. Cayot, S. Collett, A. Currylow, I. Das, T. Diange, J.R. Ennen, G. Forrero-Medina, M.G. Frankel, U. Fritz, G. Garcia, J.W. Gibbons, P.M. Gibbons, G. Shiping, J. Guntoro, M.D. Hofmeyr, J.B. Iverson, A.R. Kiester, M. Lau, D.P. Lawson, J.E. Lovich, E.O. Moll, V.P. Páez, R. PalomoRamos, K. Platt, S.G. Platt, P.C.H. Pritchard, H.R. Quinn, S.C. Rahman, T. Randrianjafizanaka, J. Schaffer, W. Selman, H.B. Shaffer, D.S.K. Sharma, H. Shi, S. Singh, R. Spencer, K. Stannard, S. Sutcliffe, S. Thomson \& R.C. Vogt. 2018. Global conservation 
status of turtles and tortoises (Order Testudines). Chelonian Conservation and Biology 17:135-161.

Rueda-Almonacid, J.V., J.L. Carr, R.A. Mittermeier, J.V. RodríguezMahecha, R.B. Mast, R.C. Vogt, A.G.J. Rhodin, J. de la Ossa, J.N. Rueda \& C.G. Mittermeier. 2007. Las Tortugas y los Cocodrilianos de los Países Andinos del Trópico., Panamericana, Formas e Impresos, S.A., Bogotá, Colombia

Silva-Galvis, J.D. \& M.L. Ortiz-Moreno. 2019. Genética de Podocnemis vogli: Estado actual del conocimiento y perspectivas. Pp. 96111. In O. A. Rodríguez-Fandiño, A.G. Cortés, J.A. RodríguezPulido, W.J. Hernández, N.E. Matta Camacho, M.T. Nieto-Vera,
M. Vargas-Ramírez, G.A. López, A.D. Jiménez \& R. Antelo. El Galápago Sabanero: Estudios en Búsqueda de su Conservación. PAREX Resources and Dirección de Investigación Unitrópico, Yopal, Colombia.

Tesche, M.R. \& K.E. Hodges. 2015. Unreliable population inferences from common trapping practices for freshwater turtles. Global Ecology and Conservation 3:802-13.

Viloria, N.A. \& M. Forti. 2015. Abundancia, estructura de tallas y proporción de sexos de Podocnemis vogli (Müller, 1935) en el Hato Masaguaral, Estado Guárico, Venezuela. Memoria de la Fundación La Salle de Ciencias Naturales 72:21-33. 